\title{
Visualisation of the "Balkan road": Media representations of the refugee crisis at the periphery of Europe
}

\author{
Ksenija Vidmar Horvat (ksenija.vidmar@ff.uni-lj.si) \\ University of Ljubljana, Slovenia
}

This article investigates visual representations of refugees in the Slovene public sphere at the time of the opening of the "Balkan Road" refugee route in 2015. The article begins with a comparative historical view of media depictions of refugees after the break-up of socialist Yugoslavia. It is argued that the early depictions were region specific and dependent on European Union (EU) integration discourses of a post-socialist transition state. In contrast, in 2015 public memories of World War II and transnational solidarity were invoked. The paper then focuses on two cases, a newspaper series I Am a Refugee and a photograph entitled The Path, which diverge from the conventional institutional framing of the refugee. The analysis draws on critical theory of visual counter-narratives to investigate these documents' potential for re-humanizing the figure of the refugee in the EU.

Keywords: Refugee crisis, Balkan road, Counter-narratives, Trauma, Visual culture

\section{Introduction}

In autumn 2015, the Mediterranean region witnessed a major influx of refugees from wartorn Syria, followed by continuous refugee movements from Iraq and Afghanistan from September 2015 onwards. Their journey stretched across the Eastern Mediterranean area, along what quickly became known as the "Balkan Road". This corridor (Lunaček Brumen \& Meh, 2016) was a newly established passageway, forming a part of, in the FRONTEX classification, the "Western Balkan Route". This route had already been active prior to the critical year of 2015. In 2009, for instance, there were 3090 detected illegal crossings. In 2015 , however, the number reached 764,033 illegal passages. As previously, the main entry points were the Eastern Mediterranean portals of Greece and Bulgaria, with follow-up pressure on the borders of Northern Macedonia, Serbia, Hungary and Croatia. The intended final destinations for most of the refugees were Germany, France and Sweden.

A decisive moment occurred on 15 September 2015, when Hungary closed its borders with Serbia, which rerouted the exodus through Croatia, the southern neighbour of Slovenia. At the Slovenian border with Croatia, the situation was exacerbated when, faced by the pressure of large numbers of incoming refugees, Croatian authorities set up organized transport from Serbia to Slovenia. On 18 September, a convoy of buses ended its journey at the border crossings of Rigonce and Obrežje, while the train wagons with the refugees continued their travel to the railway station at Dobova. The Slovene police closed the border and allowed passage only to a small number of people. In despair, some tried to cross the border across the Kolpa River. For several hours - even days - people were kept in the open. At Šentilj's crossing to Austria, they were left in cold and wet weather on the muddy 
grounds, at first with no sanitary or food assistance. In the following days, humanitarian help was organized, but non-registered organizations or individual volunteers were prevented from entering the sites unaccompanied. Communication with the refugees was close to impossible, thanks to fences and the police presence. As one volunteer reported, "We have offered food to tens of thousands of people without knowing who they are, where they come from and why they are here" (quoted in Lunaček Brumen \& Meh, 2016, 30).

The worrying reports from the sites reached the mainland thanks to various testimonies from the campsites. In this article, though, I focus on two cases of representation by authors who witnessed the events at the border and later reconstructed them into visual narratives of the trauma of the refugees. The first example was created by two authors, visual artist Vesna Bukovec and writer Widad Tamimi, who both volunteered at the camp sites. Their joint work evolved into a series of twelve refugee tales, published in early 2016 in the major Slovenian daily newspaper Delo. The second example is a documentary photograph entitled The Path, taken by Borut Krajnc at the Croatian-Slovenian "green border" at Rigonce. The photograph first appeared in the Slovenian weekly magazine Mladina, and was later presented in a gallery context as an autonomous work of (documentary) art.

In my analysis, I treat both works as counter-narratives. Each of the two presents its own sets of challenges to the mainstream, conventional way of thinking of the figure of the migrant - paradoxically, the first by defeating and the second by employing a convention of representing the refugee. In both cases, the mobilization of the counter-ideology of the text demonstrates a possibility for critical engagement beyond humanitarian help as the only possible action at hand; and indicates a way of how, concerning the discourse of migration, European public sphere can be challenged and redefined in a more emancipatory narrative construction. In the paper, the challenge is formulated first through a comparative historical perspective on media depictions of refugees in Slovenia after the break-up of socialist Yugoslavia; and, second, in light of recent calls for a "new narrative of Europe", by underlining the role of public memories of solidarity at the periphery of the EU.

\section{Media images of the migrant}

Media coverage of the 2015 refugee crisis could be categorized as emergency news (Chouliaraki, 2006). As described by Chouliaraki, emergency news focuses on representation of human suffering, which results in pity from the audience. Faced with troublesome images of human trauma, such as those captured by news reports on rescue missions of migrants in the Mediterranean Sea, the viewer is inserted into the representational domain, which Chouliaraki describes as "perceptual realism". This concept frames the news in a way that stirs an emotional reaction and, by means of dramatization suggesting urgency, mediates between the on-screen drama and the viewer's moral response. However, perceptual realism may not suggest just the need for an action that is based on the assumption of the viewer's sense of pity; it may be equally effective in triggering resentment (assigning to the victim a reckless adventurism) and demands for action that require a repressive intervention. Moreover, as Chouliaraki claims, visual dramatization of the suffering, combined first with the images of dangerous seas and overcrowded boats, and second with the follow-up scenes focusing on the aid workers in protective clothing, paints the figure of the refugee as both a subject in need of help and a subject presenting a threat - whether to security, health or culture. In this semiotic mapping of the suffering, racial connotations interfere with humanitarian discourse. "This is the primordial and unreflexive belief of our culture, that the racial 'other' contaminates and threatens our own 'purity'." (Chouliaraki, 2006, 130). Such a scenario is a "robot like machine of humanitarianism", to quote one volunteer at the Slovene refugee camp (in Lunaček Brumen \& Meh, 2016, 30); this depersonalized contact between the aid worker and the 
person in need draws a line between "us" and "them", in the process dehumanizing the vulnerable as dangerous and contaminated "masses".

In his own analyses of media spectacles of rescue missions in the Mediterranean Sea, de Genova (2013) argues that the humanitarian spectacle serves the purpose of racist inclusivity, to be followed as the next stage of integration of migrants into the dominant European societies. Moreover, he argues, visual spectacles suspend spectators' potential resentment towards global injustice: as they follow reports about victims (especially women and children), these spectacles divert their attention towards the humanitarian activities of the West. As other scholars of migration (Andersson, 2014; Calavita, 2005; Carr, 2015; Dines, Montagna \& Ruggeiero, 2015) argue, the humanitarian narrative of refugees broadcast by mainstream media is used to divert attention from political, economic and other causes of expropriation and deterritorialization of people, ultimately shadowing the implication of the West in the misery that appears to have a universal character - making it a "global state of affairs".

However, if the above discussion emphasizes that the implied racist discourse of the emergency news is pertinent to the hegemonic Western media, symbolism of suffering may take a different route when observed in the context of peripheral or semi-peripheral EU states such as Slovenia. Here, too, we are faced with attempts at racialization of the suffering "other", by which the viewer of the emergency news is reaffirmed in a position of racial and cultural superiority. In fact, as Mihelj's (2004) comparative study of news coverage by Slovene news media of Bosnian refugees in 1992 and "illegal migration" in 200001 suggests, the rhetorical framing of the migrants served the purpose of elevating the Slovenian public to the image of a European nation. Henceforth - especially with regard to the Bosnian refugees - a common past with the suffering people fleeing the war-torn region was effectively erased from the narratives while the role of Slovenia as the "threshold of the West" was emphasized. As Mihelj (2004) comments, calling the people in need "Bosnian refugees" was not just "a matter of instituting a difference between two nationalities, but much more a matter of drawing a distinction between different civilisations and, inter alia, between 'Europe' and 'the Balkans'" (Mihelj, 2004, 11). However, in the 2000-01 representations of "illegal migration" - a term used to cover a diverse body of asylum seekers and economic migrants from Africa, Asia and the ex-Yugoslavian region - news coverage created a more ambiguous discourse. At the turn of the century, Slovenia was positioned closer to the East (and the Balkans), as was also the case immediately after the collapse of the federal Yugoslavian state. News media depicted the country as a double victim, on the one hand under the pressure of requirements regarding migration control coming from the West, but on the other under the pressure of migration from the East: "As a future member, obliged to follow the rules set by 'the West', Slovenia was presumably forced to become a 'sanitary cordon' of 'fortress Europe'" (Mihelj, 2004, 11), which redirected the politics of the emergency news. Instead of focusing on the migrants' tragedies, national media embarked on self-victimization. A study by Pajnik, Lesjak-Tušek and Gregorčič (2001) of 2001 public discourse on immigrants conveys a similar, yet slightly more disturbing picture of racialization, which occurred once the refugees - victims of "security measures" - were placed in the inland detention camps.

\section{The Balkan road in Slovene media}

Media coverage of the 2015 refugee crisis shows a similar tendency to depict refugees as a threat lurking from behind the borders to invade, destabilize and disrupt the peaceful cultural landscape of the country. The narratives presented through both visual and verbal language indicated anticipation of "flows", "waves" and "tides" of strangers "flooding" the lands of the states along the Balkan Road. In a critical discourse analysis of several Slovene print and electronic media, a group of scholars showed how a common thread running 
through a diverse body of news outlets, ranging from quality to tabloid formats, was the polarizing view of the divide between "us" and "them". Whether dressed in a "moral dilemma" (Vezovnik, 2017), or "moral panic" engulfing the discourse of cultural threat (Pušnik, 2017); governed by conventional codes and neutralism as a constitutive element of professional self-presentation in political journalism (Luthar, 2017); through legitimation of migration policy (Pajnik, 2017); or portrayed as humanitarianism (Jontes, 2017), a sharp line of demarcation was drawn that suggested an intrusion on the part of the refugees, disturbing the "normalcy" of national life. In contrast to the previous two settings of the European context as the backbone of legitimation of anti-migration sentiment, in 2015 a different concern was mobilized. As shown by Vidmar Horvat (2017), media paranoia coincided with the fear that if it were unable to stop the illegal crossings, Slovenia would be left out of the EU power centres at Brussels. This struck a chord as news about a proposition to create a temporary "mini Schengen", containing only the core circle of Western EU Member States, trickled out through the media (Vidmar Horvat, 2017).

Consequently, in August 2015 Slovenia joined the EU Brussels chorus, which condemned Prime Minister Victor Orban's announcement of wiring Hungary; in November, the media could already follow the military units that had begun to install the fences. As the razor wire was installed at a "speed of 150 meters per hour", as one report put it, manipulation of the numbers of refugees approaching Slovenia, as well as fears of "back-flows" from Austria and Germany, turned public attention to migration hysteria. An already available tool within the Schengen border industry (Carr, 2015), hysteric anticipation of flows and floods of people to invade the lands and homes of the peaceful Western world was used to expedite the legitimation process for wiring the borders while attaching itself to the image of the nation victimized by troops of migrants.

While the image of masses of refugees pressing their bodies (and fortunes) against the fences of the Schengen West dominated the conventions of media coverage of the crisis, an oppositional solidarity bloc of voices emerged, raising a different public mirror to the scenes from the borders. Letters written by readers begun to arrive to the media headquarters, issuing protests by invoking memories of the twentieth century. In "Concentration Camp Slovenia", a reader wrote, "It is sad to see that we are using the same methods as were used during the war by the aggressor." In December 2015, public protests against the fences at the borders culminated in a newspaper's front-page title, "This is Incomparable Even to the War Times". People spoke of "sad, terrifying scene, reminiscent of the last war" in a reference to the wired zones of Slovenia during World War II that appeared in the newspaper column "A Wired Mind". One newspaper comment suggested that closing the borders at the Balkans would revive painful memories, while titles such as "Again, Europe with Iron Curtain" and "Refugee Holocaust", and comments such as "I hope that they do not raise a concrete Berlin wall again" referred to concrete past episodes of border and containment violence that occurred in the twentieth century (all quotes in Vidmar Horvat, 2017).

The emergence of this alternative public voice warrants a sociological investigation of the counter-narratives and their power to contest and destabilize the dominant narratives. However, presented in the form of readers' letters, critical commentaries or coverage of groups of protests, they may appear to be marginal, unfolding at the fringes of the public sphere and demonstrating a "narrow" segment of an oppositional view of the crisis. Yet when presented as part of the "core" - that is, as an integral or even central site of institutional setting - the registers of meaning and power shift, as my case studies will demonstrate. 


\section{Counter-narratives between Western theory and Cold War reality}

Counter-narratives simultaneously inhabit an ambiguous place of being within and outside the dominant discourse. As argued by scholars of the field (Bamberg, 2004; Bamberg \& Andrews, 2004; Andrews, 2004), the focus on counter-narratives provides an insight into ideological struggles triggered by dominant cultural discourses. This is because counternarratives are relational: they only make sense in relation to what they are countering. However, by the very virtue of their oppositional character, they also contain the aspects of hegemonic narratives, which they try to contest, critique or refute. The dominant and the oppositional are therefore mutually constitutive, "unveiling in their opposite the attempts at meaning production which define the ideological frame of the narrative" (Bamberg \& Andrews, 2004, x). In Andrews' $(2004,2)$ words, "Counter-narratives exist in relation to master narratives, but they are not necessarily dichotomous entities"; they may be running against the dominant stories, but they are also shaped by them.

Studies of narratives have been associated mainly with discourse analysis in the field of psychology. As argued by Bamberg $(2004,354)$, "narratives provide the possibility of a format that has become the privileged way of fashioning self and identity". The method delineates a biographic approach to understanding how people construct their selves, as well as allowing us "to dissect how selves and identities are constructed in both spatial and temporal terms" (2004, 356-357). As Bamberg (2004, 356-357) also notes, this may be especially valuable to apprehend transformations of the self when people are crossing into new spatio-temporal territories, in terms of both intimate biography (such as parenthood) or socio-economic repositioning (such as immigrating to a new country). The implication here is that narrative analysis provides an insight in how people reconstruct themselves in relation to experiences and in anticipation of new life developments. In brief, the focus is on individual psychologies and the constructions of life stories, which mediate between the expected, "normalizing" discourses of change and the individual attempt to define oneself in both compliance and opposition to the norms and social routines.

When studying the refugee crisis, the narrative approach could be an important tool to gather insights into transformations of personal biographies and the notions of self of the people who were forced to leave their homelands. In this research, however, I employ a sociological approach, with the method of counter-narrative providing a tool to observe the construction of the collective self of the dominant society when met with the challenge of the migration crisis. As the above quoted reader's letter suggests, memory plays an important role in the articulation of the narrative of collective identity. By using media narratives, I follow Bamberg's argument that by studying oppositional narratives, we can open up a space for more plural and emancipatory "biographies" of the public:

"If it is possible to delineate more clearly where and how discourses that run counter to hegemonic discourses emerge, and if it is possible to describe the fabric of these counter discourses in more detail, we should be able to make headway in designing alternative strategies to public, institutionalized power relations, resulting in more egalitarian reciprocity and universal moral respect." (Bamberg, 2004, 353)

Bamberg's approach is to focus attention on the interaction between master narratives and oppositional narratives, or counter-narratives. Master narratives set up interpretative routines; they are "'frames' according to which courses of events can easily be plotted, simply because one's audience is taken to 'know' and accept these courses" (Bamberg, $2004,360)$; they tend to naturalize and normalize the meaning to the point where we accept the proposed reading as the only option. Counter-narratives oppose routine meaning construction by suggesting alternative readings and courses of action. The interplay between the two, as Bamberg strongly underlines, is not settled in advance: neither master 
nor counter meaning exists prior to their mutual interaction, and both are contingent on and defined by heteronomous social settings - both biographic and institutional.

When transferred to sociological analysis of collective narratives of identity, this approach demands a historical perspective, which considers the narrators' social and political identity as well as their positioning within the institutional networks of power. This suggests a further division: that counter-narratives may operate at different levels of social life. For the purpose of simplification, I will consider these levels as macro, meso and micro fronts on which power is being resisted. To illustrate, a counter-narrative at the macro level may entail a broad historical turn (away) in the realm of ideas and notions of truth. The postmodern turn represents one such counter-narrative, undermining the "grand narratives" and claiming to objective truths of modernity. Postmodern counter-narratives, as Peters and Lankshear (quoted in Giroux et al., 1996, 2) state in an earlier contribution to the topic, aim at disturbing "foundational myths concerning the origins and development of an unbroken history of the West based on the evolutionary ideal of progress". Regardless of how we actually theorize the postmodern turn - as a radical break or a cultural logic that continues to be defined by capitalist mode of production (Jameson, 1991) - it has achieved a broad enough academic as well as popular status to be considered a shift in narrative with the power to intervene in macro institutional as well as micro levels of cultural life of the West.

Counter-narrative at the meso level indicates institutional support for or a backup of the counter-narrative coming from a place of hegemonic power. For the purposes of this article, this could be illustrated by a historical case of the socialist state involved in Tito's nonalignment movement, which was a consequence of Yugoslavia's breakup with Stalin (and, some would argue, its colonial communist rule). It therefore originated in a previous act of resistance to imperial power and, through further development, became a global alternative to modernization as it was implemented by both the West and the East (Balibar, 2004). As critical scholars and public institutions in the ex-Yugoslav region have recently turned their interest to this legacy (MSUM, 2019; Štiks, 2019), new generations of readers of socialist history are now able to become acquainted with a different version of the past. In this version, the resistance to the communist regime coexists with civic loyalty to ideas of transnationalism; as a consequence, it is concerned less with the repressive aspects of party rule and is more sympathetic to the non-aligned state of Tito's Yugoslavia. This case is relevant as it partly frames the debate in Slovenia regarding how to treat immigrants throughout the transition (Vidmar Horvat, 2009) and has shaped the solidarity discourse in recent years (Vidmar Horvat, 2012).

At the micro level, it may seem that the counter-narratives hold the least power to make changes at the broader social level. In many instances, the cultural theory of counter-narratives indeed exposes everyday resistance, articulated through narrating counter-stories, including memories, as being "only" of the "self". Scholars of post-socialist memories unveil how counter-narratives of the past may become a mobilizing force to resist hegemonic narratives of the post-socialist transition. Here, counter-narratives struggle with historical revisionism, including the twentieth-century history of Europe, to elevate from the debris of censorship and official amnesia the evidence of past values, embraced in notions of global justice, solidarity and human rights (Velikonja, 2014). Again, this is relevant to civic engagement as it relates to the fate of the refugees in Slovenia.

In summary, when using the conceptual tool of counter-narratives in sociological analysis, attention should be paid not only to how resistances are organized in relation to dominant, official, hegemonic narratives, but also to what are the distributive powers of intervention into history - both biographic and social - when involved in mutual contests of representation. With the following case studies of newspaper and photographic counter-narratives, I will explicate the interplay between the two, arguing that the historical contact between 
biographic and cultural counter-narratives has a considerable role to play in the articulation of resistance to the mainstream regimes of truth. Instead of focusing on the reader and their memories of past solidarities, the attention will be on the image of the refugee, presented as a biographic subject with memories and as a site of an alternative encounter with the trauma.

\section{Case One: I Am a Refugee}

I now turn to my two cases of counter-narratives. Both cases provide a valuable insight into the power of the counter-narrative when playing around, against, and with the convention of representation - the on-site media coverage of the crisis through the voices of the subjects in trauma in the first case, and by employing the convention of the documentary photography in the second case - while still appearing in the cultural setting of the mainstream institutions. In their combined effect, the two media interventions indicate the possibility of changing the dominant cultural relation with the other in a peripheral border state; as well as contributing to the reformulation of the notions of (global) solidarity and hospitality in the European public sphere.

The first concerns a newspaper series I Am a Refugee ("Begunec_ka sem"), published by the Slovenian national daily Delo over twelve Mondays in a row, beginning in January 2016. The authors, Vesna Bukovec, a visual artist, and Widad Tamimi, an Israeli born writer who lives in Ljubljana, volunteered in the two refugee centres at the border with Croatia, where they gathered the stories for the series. Though documentary in nature as far as credibility of the setting and its protagonists is concerned, the series fictionalized the testimonies, merging the life stories of various refugees into a fictional narrative. Instead of including documentary photographic material, Bukovec contributed hand-drawn illustrations.

I Am a Refugee was an artistic project with a reportage value. While concealing the real identities of the camps' inhabitants, the personalized voices used by Tamimi added the anthropological dimension of the people behind the fiction. In the original texts, the split between fictive and biographical voices was indicated by the change of font (here, passages without emphasis refer to the off-voice of the narrator as reporter:

My father is a handicapped person and you took him away, where is he? Tell me, where is he? He is all I have left in the world, I promised to take care of him, tell me, where he is!" Ahmad is 17. He came to Slovenia by foot. In front of him he was pushing his father in a wheelchair. After crossing the Slovenian border police offered him a ride. The father was loaded onto an ambulance and Ahmad continued walking. (I Am a Refugee: Ahmad, 17 years, Delo, 25.1.2016)

"I hate you for making me leave alone with two children ... We said goodbye in the harbour, after you helped me to put life-jackets onto the kids, while they were hugging you and pleading with you to stay with us." (I Am a Refugee: Fatima: "I hate you, my love", Delo, 1.2.2016)

"I was hugging my little sister Lina ... Lina is my first sister, the others are children of my father's new wife. My real mother stayed in Syria with her new husband." YZN is eleven years old. In Croatia he was separated from his family with whom he escaped from Syria. He arrived in Brežice at two in the morning, cold and wet from the rain. (I Am a Refugee: YZN, eleven years, Delo, 7.1.2016)

"Dear Ava, I arrived to Europe in good health. I miss you, little sister, I think about you a lot and in the night, before I fall asleep, I look at the photograph of us together. We had it taken just before I left. How good it is that we went to the photographer." (I Am a Refugee: Jusef, Delo, 14.3.2016) 
"We arrived to Slovenia, my love. Why do you not smile? Slovenia ... that's right." (I Am a Refugee: Sami, Delo, 7.3.2016)

"I'm sorry to have made you sad too. This is my story and it's not right that I made you sad too." (I Am a Refugee: Jusef, Delo, 14.3.2016)

In Western media conventions of representation, refugee-related news is brought to the audiences in two main, interrelated forms: one revolving around depersonalization; the other, in contrast, using techniques of over-humanization of human suffering (Chouliaraki, 2006; Rosler, 1999). As they both rely on the legacies of documentary - that is, realistic depictions of human deprivation, they work in tandem without creating a tension or contradiction of meaning in the reader. The refugee is both a subject with no name and, as the ultimate embodiment of "bare life", the representation of the human essence. In addition, the refugee stories usually begin in an empty "now". As Wright (2000) indicates, the refugee's life seems to begin only when arriving to "us"; there is no concern for the immediate past that has made someone into a refugee, nor any genuine interest in knowing the refugee as a human being who, like "us", embodies emotions, memories, passions and sorrows.

I Am a Refugee confuses the voice of the biographic and the universal subject, rendering it impossible for the reader to smoothly embark on the drama of humankind. This is done at the level of both the verbal and visual set-up of the narrative. In the verbal setting, the family-related contexts of the refugee stories prevail. It is this context that frames the loss of intimacy, safety, love, future (growing up and growing old). These are universal themes of human life, but fictional names with real family backgrounds make it difficult for the reader to easily choose either the conventions of fictions or the news-related conventions of identification. If siding with the option that this is only fiction, into which the first-person voice of Widad Tamimi translates different biographies of actual people, composing out of them a single "refugee story", then this setup for the identification precludes the possibility of blaming the actual refugees for self-imposing the injury of expulsion. If opting for a real person's autobiographic story, resentment towards actual refugees may arise, but it is harder to ignore the emotional contents (of fatherhood, sisterhood, spousal love) of their refugee condition. I Am a Refugee contains the voice of the refugee as a biographical person, the refugee as a fictionalized person and the writer as the author of the media narrative. This merger in genre and temporal heteroglossy (time of witnessing, time of writing, time of publishing) places Tamimi in the role of the reporter, thus allowing her to give authenticity to the voice and at the same time taking away its power to fascinate as an authentic document of a particular life story. The confusion of voices unsettles the possibility for one-directional sentimental response, or the reader's comfort to attach the empathy to the subject in the story, who the reader knows - despite appearing in the newspaper - is wholly fictional.

Visual images of migrants in print and electronic media by default operate as texts of anonymity; by stripping the subjects in the pictures of their names and life stories, they acquire the legitimacy to speak of universality. As Martha Rosler $(1999,319)$ comments on the (in)famous image of the Migrant Mother, the subject in the image is degraded to the status of an object - a voyeuristic site to observe the ahistorical narrative in the making, contained in the eternal topic of the "suffering of mankind". The visual representation of the series - the use of illustration - paradoxically leans towards de-objectification. Illustrations in the I Am a Refugee project invoke Art Spiegelman's two-volume novel Maus, where he uses illustrations of animal characters of cats (Nazis) and mice (Jews) to present his father's memorial narrative of Auschwitz. As Leventhal (1995) notes, reduction and compression of images in a graphic novel serves the function of distancing - not only from the brutality of Nazi extermination plans but, above all, to prevent evoking a simplified response from 
the reader. In this way, the text forecloses the possibility of historic catharsis. The illustrated image in Haideri's story in I Am a Refugee recreates a similar situation. Haideri escaped while heavily pregnant and gave birth in Greece, then lost any trace of her newborn. The picture in her story depicts a live body of a baby lying in a spiral reel of razor wire. Attached to the baby's hand is the paper tag with the inscription "Refugee" (Figure 1).

Figure 1: I Am a Refugee: Haideri - illustration.

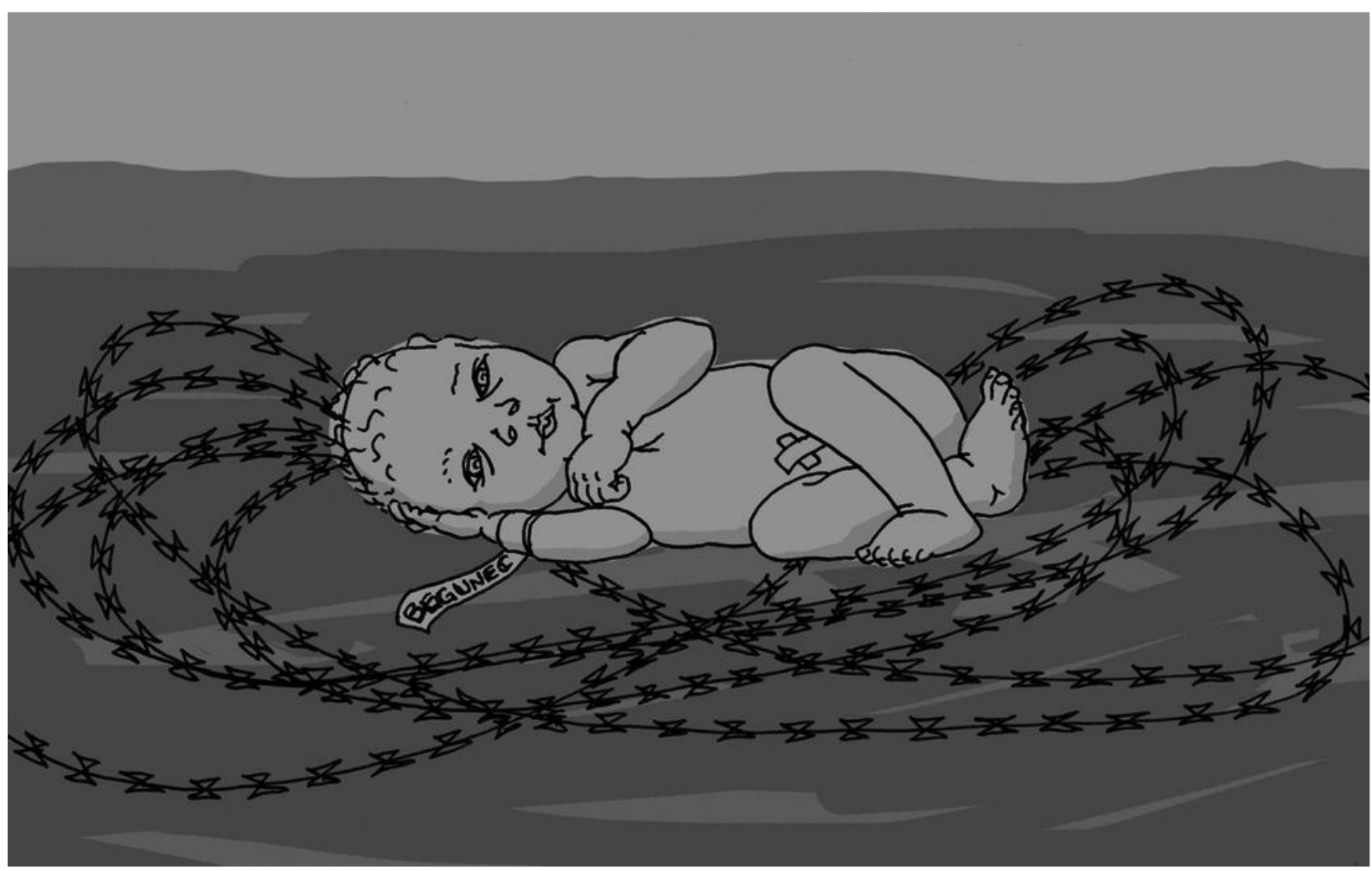

Source: I Am a Refugee: Haideri, Delo, 29 February 2016.

The image reiterates the image of Alan Kurdi, the three-year-old refugee from Syria who, together with his mother and brother, drowned in the Aegean Sea. The photography which first appeared on social networks and later in all major media in August 2015, has acquired the status of flag-bearer for the trauma of Syrian refugees stuck on Europe's doorstep. In I Am a Refugee, the reduction of the wholesome subject to lines and streaks in illustrations could never become an iconic image, as was the case with the photograph of dead Kurdi. This is precisely for the opposite reason than is usually the case: the image of Alan Kurdi became "famous" not because he had no name but because his body was inscribed with history of a known family. The name grants public (legal, political) status to naked life thus revealing a person who we are able to mourn (McRobbie, 2006). The image is no longer a display of an unjust death of a child refugee, but rather a depiction of deceased Kurdi. The fact that his mother and brother died with him triggers the formation of a story behind the image - a story of a family who will never reunite. Based on this public display, a spectator can imagine their own feeling if they were to be placed in the role of the parent of a dead child - the narrative opens up to allow for identification and mourning.

The baby refugee with no name, when taken in isolation from the context, belongs to no concrete mother but rather tells the destiny of a whole generation. Moreover, he is alive, lying on his back, which - in dramatic opposition to the dead child lying on his belly in the photograph - suggests a history still occurring, with no closure and no actual death to mourn. The illustration is with us, a living testimony of suffering that faces us directly, in the eternal present. However, because the image is also an illustration of the (hi)story of 
concrete motherhood behind it, it cannot be easily depersonalized - its raw and objectlike presentation of a newborn baby's body notwithstanding.

\section{Case Two: The Path}

In her discussion of the relationship between visual and verbal aspects of media realism, Lillie Chouliaraki (2006) differentiates between indexical, iconic and symbolic modes of news coverage. The indexical meaning is based on the correspondence between the news story and the reported events; the iconic and the symbolic meanings move the realism of the event away from "pure" description to a more abstract level. The latter triggers psychological realism - a representation of reality that "appeals to our sense of humanity and justice" $(2006,120)$. In this capacity, Chouliaraki argues, both iconic and symbolic meanings are in fact more effective - they bring the reality of suffering to us in a way that is imposing and compelling more than the indexical news. Aesthetically, this is carried out through the juxtaposition of a mise-en-scène of suffering and the public appeal of the news.

In photography, the functions of the verbally and visually disseminated meaning may merge. As Barbara Harrison (2004) discusses in relation to the photographic images of the everyday shots taken by ordinary people, photography can be read as containing a visual narrative. She argues that:

"If we wish to use the visual within narrative inquiry we must examine if, and to what extent, the visual can be used to construct narratives, the relationship to or dependence on written or verbal narration, and the ways in which visual narratives can provide us with data on experience." (Harrison, 2004, 115)

In her focus on everyday photography (for instance, photographs taken on holidays, at family reunions and so on), she suggests that, "Photographic images have a material and symbolic significance that act as important vehicles of communication: communication that contributes to the fabric of social relations" (Harrison, 2004, 133).

In The Path by the photographer Borut Krajnc (Figure 2), the narrative emerges from the image, which is split into two halves. The upper part includes a woman in pink shawl around her head, carrying in her arms a child whose face is covered in cloth. The woman looks upwards, into the sky. Her image is fully illuminated. Behind and on her right side is a crowd of people in grey blankets, apparently refugees like herself, non-illuminated, their bodies multiplying out of camera focus and into the darkness of the night. On woman's left side is a man in a light-brown jacket, also standing in bright light. The bodies in the upper part of the image are visually contained within a space demarcated by the police belt stretched vertically across the photograph. Just underneath this visual bar, a woman in a red hood is sitting with a younger child in her arms; she is looking downwards. An older girl in a red hood stands next to them, turned left and with her head tilted up, again towards the sky. 
Figure 2: Borut Krajnc, The Path, 2016

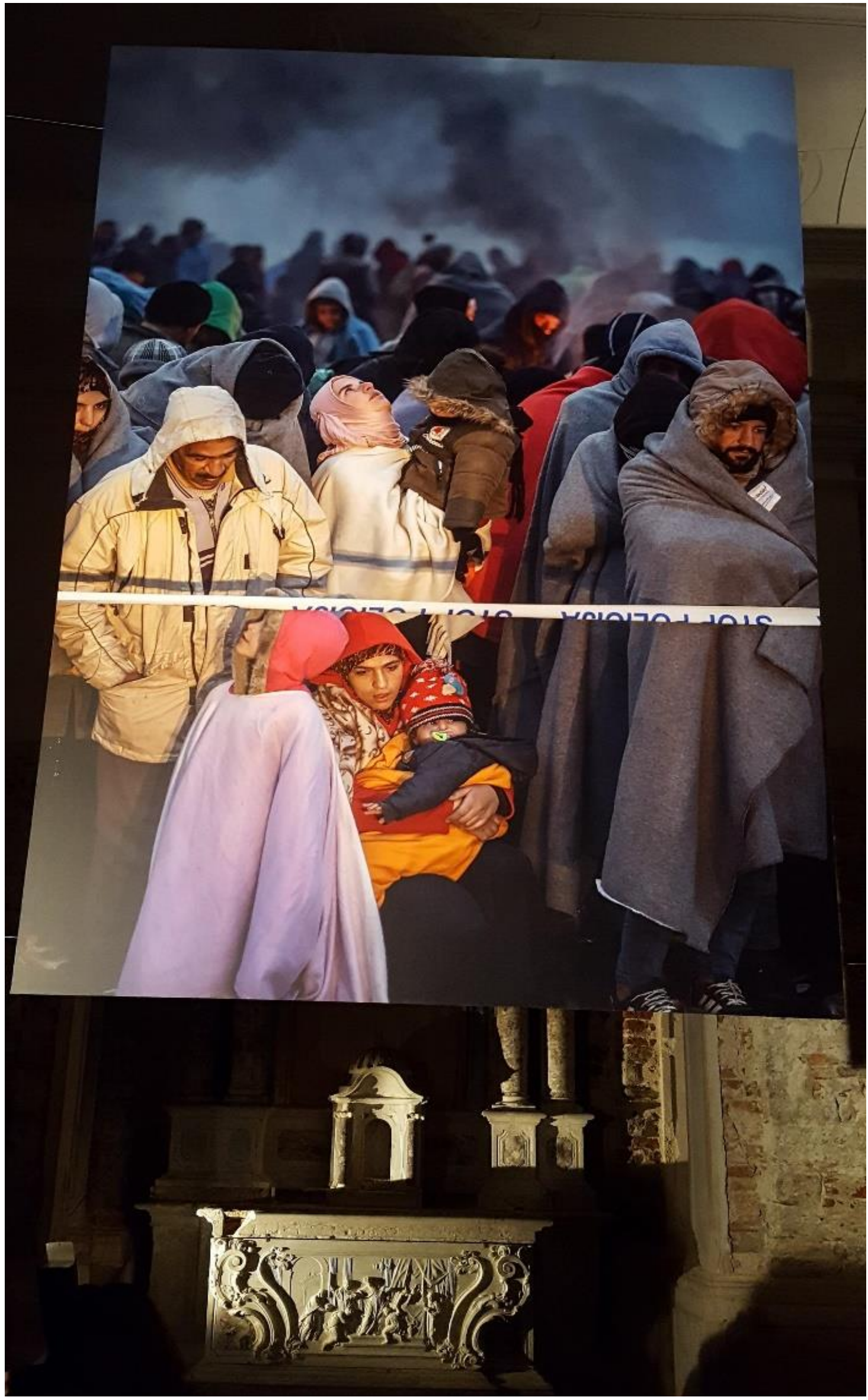

Source: the author. 
Borut Krajnc, the creator of the image, explains the background to the photo. The image was shot on 25 October 2015, at six in the morning, at the border of Rigonce. "In the middle, we see faces, illuminated by the fire. The refugees made the fire to keep themselves warm. The other light comes from police cars." He titled the photo The Path, following the lyrics by local musician Drago Mislej Mef, himself dedicating the poem to the refugees. In the image, he saw a painful testimony of the suffering of the refugees, which he followed on their Balkan Route in autumn of 2015. He also wanted to present the photo individually, as a testimony to our times.

In June 2018 , at the height of the tourist season, he accepted an invitation by a local parish to present his work in the Slovenian coastal town of Piran. Krajnc exhibited his work as the only item on display, in the setting of the small church of Marija Zdravja, itself seriously "wounded" in construction by weather and seawaters. He said:

"Now the photo is in the context which I wanted from the beginning - in the silence of a spiritual place, which is damaged, hurt as the people in the photo. Here, one can look inside himself while facing the suffering of the other. It is right that this is placed next to the sea-we know how many refugees had to cross the inferno of the Mediterranean Sea" (Gombač, 2018).

The exhibited photo, 155 by 225 centimetres in size, reiterates a biblical scene. As described in the leaflet accompanying the exhibition, it shows the mass of immigrants who could stand in for angels and priests, with garments as sacred clothing that covers "the wounded, vulnerable and scratched body"; a man in a light cardigan is a witness (Joseph, the carpenter); the woman (Mary) carries the "Child, with a hood that covers a white, obscured concealed face"; and a forbidden arrival in Jerusalem". It is a powerful allegorical image, which could easily become another iconic photograph of the 2015 refugee crisis; however, I would argue that it defies the possibility of an iconic fame (at least in the West) as it is narrated in reverse to the biblical reference.

Terence Wright (2000) argues that visual representations of refugees frequently invoke Christian iconography: viewers, Wright $(2000,2)$ writes, "find accord with such images (with which they are already familiar)" and, furthermore, "may evoke a familiar story-line". Joseph and Mary's "Flight into Egypt" and "Madonna and Child" are regular connotative references by which refugees are depicted in contemporary media, contributing to both a stereotypical image of "the refugee" as an expelled person (but, as we have seen, with no real interest for their prior lives) as well as inviting a Christian ethics of compassion. The Path may be classified as a case of a visual counter-narrative, despite the fact that, at first glance, the photograph reiterates what appears to be a visual convention. This can be argued because the photograph employs the conventions of documentary photography. In news documentary photography, the subjects in the picture have no say about how they will be portrayed. They may have access to the camera and voice, but only as contributing to the non-obtrusive, objective view of the camera. Often, as was the case with Dorothea Lange's Migrant Mother, or, for that matter, Afghan Girl, shot in the refugee centre by Steve McCurry for National Geographic in 1984, the subject in the picture may remain unknown and nameless for decades. The convention of anonymity, as Chouliaraki $(2006,65)$ argues, leads to the mobilization of a meaning that is predetermined - namely that the narrative behind the image is one of suffering and distress - and is thus predicated on the invocation of pity.

When a photograph acquires the status of an iconic image (as both Migrant Mother and Afghan Girl have), it begins to create public memory. The naked and napalm-burnt Phan Thi Kim Phuc is the iconic image of the Vietnam War, Richard Drew's The Falling Man is the iconic image of 9/11. As Lev Kreft $(2010,267)$ points out, however, "icons make up memories that are tailor-made for the desire for oblivion". One might argue that especially 
traumatic images - that is, those that are supposed to leave the deepest and most irreversible impressions in public memory - become iconic precisely because they pre-guarantee oblivion. Their iconic force originates in the assurance of the numbness that such traumatic images carry with them (since it is perfectly clear that something similar was bound to happen eventually). Hočevar $(2010,82)$ says that, "Photography is the perfect medium for the depiction of traumatic events. It conflates something cruel, a premonition of a disaster that has inevitably already happened." At the same time, photographs of trauma "refine" this numbness through moral satisfaction - "I endure in the face of terror and keep on looking" as Susan Sontag (2006) points out.

This is not the case with The Path, which uses photography as a site of iconic recognition. However, when exhibited in a church, it triggers an analytical (not the emphatic) reading. It asks the reader to re-memorize the cultural tradition and, precisely because of its placement in the institutional context of the church holding the name of Mary (Mary Health of the Sick), legitimizes the call for making the links between the two women. Hence the refugee woman looking into the skies, like Mary, is an icon of human suffering who, through reference to the biblical imagery and not because of the genre of documentary, does not need to have a name of her own. Her depersonification, a staple of documentary photography, in fact works in the opposite way. Referring to a symbol of abstraction (of suffering) pins the viewer down to the realization of the actuality of the past scene involving Mary as an earlier embodiment of the refugee mother. Psychological realism induces perceptual realism, not the other way around! The reaction may be moral (an outrage, shame about one's own culture, a political protest) but, via rearranging the politics of memory, it is also a historical rearrangement of the iconic heritage of the West. Now, through the continuity between the viewer's time and the image's time, it is Mary who becomes iconically connected to this woman's actual scene of suffering. In other words, the perceptual realism of Mary's maternal suffering in the past erupts through, and is confirmed by, the psychological realism of this refugee mother's trauma in the present.

Shuman (in Bamberg, 2004, 369) argues that the empathy that arises from the trajectory of the personal and the human has the potential to destabilize meaning from the personal to the allegorical, so that the "allegorical understandings can become challenged". In The Path, the reversal of legitimation of iconic and symbolic power both disturbs and undermines the path of memory, making the present the historical reference for past abstractions. This means a political shift, whereby abstract signs of human tragedies, implanted in Western imaginaries through icons and symbols of the past, no longer stand in a secure position as universal references but are instead seeing their meaning being negotiated in every single instance of their invocation of the present.

\section{Discussion: Image as a site of traumatic encounter}

In a time defined by multiplication of spectacular images that drain our sense of history so-called compassion fatigue (Chouliaraki, 2013, 34) - photography preserves the possibility of memory by saving images (2013, 142-143). The 2015 media coverage of the Balkan Road was replete with traumatic images but, as we have also seen, the traumatic images are often placed in an (involuntary) role to bring a sense of closure. Through resorting to icons of time, they are invested with hope to reconcile with both history and memory. They address the viewer's capacity for empathy, but foreclose the sense for a history of morality.

The two counter-narratives selected here for analysis defeat this role. The moral response that they both instigate in the viewer is closer to what Patricia Violi (2012) discusses in her work on trauma site museums. As she argues, focusing on the indexical politics of representation, presentation of trauma in the memorial museums, erected in actual places of 
past crimes against humanity, lies in the spatial continuity between the horrors of the past and the visitor's museum experience in the present:

"The experiential efficacy of re-presentation or indexical trauma sites does not lie in their alleged "realism" but elsewhere, more precisely in their being a trace linking past and present through persistency of material elements over time. In other words, it relies on the supposed authenticity of traces, not the implied truthfulness of the representation." (Violi, 2012,41)

In a similar sense, I Am a Refugee could be read as a media trauma site where the experiential power of the stories comes from the sense of biographic authenticity of the fictional narratives of suffering. Of course, the original trauma site is replaced with a fictional one, but the continuity erupts through identification with the suffering subject, who is both alive (in a biographic sense) and dead (in fictional sense), or rather where the biographic fate of the actual refugee becomes one with the fictional subject - a subject with no legal existence. The traumatizing aspect of the series lies in the very "traces" of human life that one can recognize and sense as familiar; via identification with that "authenticity", the viewer understands the horror of undermining the common value of life.

In The Path, the traumatic site is represented by two actual places, which reconnect with each other through the act of exhibition: the border site at Rigonce and the church site at the coastal tourist zone. As Mieke Bal $(2006,226)$ explains in the case of migrant video projects, what distinguishes fictionalized documentary formats from purely documentary ones is that they do not present us with the facts of the truth, but rather its essence - its very substance. In this sense, they possess a special power to transform memories into the now-time: "Fiction is deployed, then, to propose prophetic memory as a tool for political action" (Bal, 2006, 226). The image is not, cannot, be frozen and forgotten in the very moment when it is consumed. It resists iconic status and claims symbolic presence. In Krajnc's own words, "This spiritual space of the exhibition could become symbolic in the sense that it opens up a possibility for an intimate humanist gaze at the refugee and migrant agony" (Gombač, 2018). To recount, this is precisely what John Berger (2006) expects to be a political mission of photography. In its official role, photography is a testimony about the depersonalized human condition. This unfortunate task, he argues, can be contested by bringing the public closer to the private. The goal must be to establish photography together with its context, to place it back into time and simultaneously historicize that time - to make it present in the now. In this way, its iconic status can become part of personal, intimate memory of history. In a retrospective way, The Path has revived an earlier context and re-sensitivised the visitor to the historicity of the suffering through its exhibition in the local church.

\section{Conclusion}

Since the 2007-2008 financial crisis, the European Union has faced a repeated series of challenges to reconstitute itself in a direction that would fuel trust and loyalty among its citizens. Indeed, in the last decade, several manifestos have been drafted, sometimes signed by the political leaders, sometimes by the intellectuals, sometimes by both. A New Narrative for Europe, first signed by Manuel Barroso, calls for a "new Renaissance" (Battista \& Setari, 2014, 128). It issues a warning that the EU does not merely entail economic growth but also the values of "dignity, freedom, democracy" (European Union, 2013). In the manifesto We are Europe signed by Ulrich Beck and Daniel Cohn-Bendit (2012), the authors remind us of the heritage of popular irony and self-ridicule that could give back to Europe some of its former energy. Further on, Beck (Brown \& Gilson, 2013) and Habermas (Limone, 2012) argue for a confrontation with European nationalisms and a reform of European modernity. We need a new vision, Beck states, "a vision for a social Europe" (Brown 
\& Gilson, 2013). Beck alludes in particular to the austerity measures and their impact on Greece and Spain, and calls for a revitalisation of European modernity by which to bring European nations back into the global arena and to assure less insecurity to European citizens. But does the call for a refreshed modernity not imply drawing on the inequality between those with political lives and those who have nothing but their naked lives? Can European modernity really be reset as a European project, i.e. a project taking place inside the borders of the EU, without taking into account the fact of global migration as its internal feature?

The 2015 refugee crisis unveiled the fragility of the European project, in part because collective biographies of the EU are multiple, often inconsistent, and, above all, defined by local memories and visions of the past. To mobilize the counter-power of these local, peripheral memories, it is first necessary that we recognize them as such - as local counternarratives that struggle for their place of power and autonomy in relation to the hegemonic centers. In the concluding remarks to his contribution to the referential volume Considering Counter-Narratives, Michael Bamberg $(2004,369)$ brings to the fore an important critical emphasis: that by focusing on narrative analysis, we gain access to a broader picture than the personal: human, shared, universal $(2004,369)$. This has to be implanted as a daily challenge, where the representation of others collides with representations of ourselves - not as demographic, cultural or identity categories, but as evidence of a common life that needs to be inspected through history, memory and rational morality.

In the case of Slovenia, popular counter-narratives are defined by resistance to the postsocialist state and its servitude to the Schengen apparatus of exclusion. Equally important are the memories of WWII, however, which provide the narrative content by which refugees' traumas could be translated into a non-allegoric discourse of global human solidarity. Local media have played a potent role in providing interpretative frames that have mediated between the "master" (Western) discourse of the refugee as the "other" and popular calls for solidarity and help. When embarking on the platform of established institutional frameworks, such as daily news media or the local church, as was the case in our two examples, and populating them with stories that look like our own lives, our symbols of goodness, our hopes - up to the moment of abrupt rupture in the biography, caused by war, famine, or other disasters of nature or politics - the lineage of humanity may become more present and more familiar, but also more historical.

This may be seen as a minor advance in the history of morality at the periphery. It may also be seen as a peripheral, but nonetheless counter-narrative advance, by which European biography can also be rewritten in regard to the master narrative of the Balkan road; as well as all of the other migration routes to the EU.

\section{References}

Andersson, R. (2014). Illegality, Inc.: Clandestine migration and the business of bordering Europe. Berkeley, CA: University of California Press.

Andrews, M. (2004). Opening to the original contributions: Counter-narratives and the power to oppose. In M. Bamberg \& M. Andrews (Eds.), Considering Counter-narratives: Narrating, Resisting, Making sense, 1-6, Amsterdam: John Benjamins.

Bal, M. (2006). Heterochrony in the act: The migratory politics of time. In M. Bal \& M. Hernandez-Navarro (Eds.), Art and Visibility in Migratory Culture: Conflict, Resistance, and Agency, 211-238, Amsterdam: John Benjamins. 
Balibar, É. (2004). We, the people of Europe: Reflections of transnational citizenship. Princeton, NJ: Princeton University Press.

Bamberg, M. (2004). Considering counter-narratives. In M. Bamberg \& M. Andrews (eds.) (2004). Considering Counter-narratives: Narrating, Resisting, Making sense, 351-371, Amsterdam: John Benjamins.

Bamberg, M. \& Andrews, M. (eds.) (2004). Considering Counter-narratives: Narrating, Resisting, Making sense. Amsterdam: John Benjamins.

Battista, E. \& Setari, N. (2014). The mind and body of Europe. A new narrative. European Union.

Beck, U. \& Cohn-Bendit, D. (2012). We are Europe! Manifesto for re-building Europe from the bottom Up. Retrieved from: http://www.manifest-europa.eu/allgemein/wirsind-europa?lang=en. Accessed 26 February 2014.

Begunci v zavetju cerkve na piranski Punti [Refugees in the church's shelter in Piran]: Gombač, A. (2018, June 4). Primorske novice. Retrieved from: https://www.primorske.si/2018/06/04/begunci-v-zavetju-cerkve-na-piranski-punti.

Accessed 18 August 2019.

Berger, J. (2006). Ways of remembering. In S. Manghani, A. Pieper \& J. Simons (eds.), Images. A Reader (214-216). London: Sage.

Brown, S. \& Gilson, C. (2013). Five minutes with Ulrich Beck: "Germany has created an accidental empire". LSE EUROPP Blog March 25, 2013. Retrieved from:

https://blogs.Ise.ac.uk/europpblog/2013/03/25/five-minutes-with-ulrich-beck-germanyhas-created-an-accidental-empire/. Accessed 19 April 2020.

Calavita, K. (2005). Immigrants at the Margins: Law, Race and Exclusion in Southern Europe. Cambridge: Cambridge University Press.

Carr, M. (2015). Fortress Europe: Inside the War against Immigration. London: C. Hurst \& Co.

Chouliaraki, L. (2006). The Spectatorship of Suffering. London: Sage.

de Genova, N. (2013). Spectacles of migrant "illegality": The scene of exclusion, the obscene of inclusion. Ethnic and Racial Studies, 36(7), 1180-1198.

Dines, N., Montagna, N. \& Ruggeiero, V. (2015). Thinking Lampedusa: Border construction, the spectacle of bare life and the productivity of migrants. Ethnic and Racial Studies, 38(3), 430-445.

European Union (2013). New Narrative for Europe. Retrieved from: https://ec.europa.eu/culture/policy/new-narrative_en

Giroux, H., Lankshear, C., McLaren, P. \& Peters, M. (eds.) (1996). Counternarratives: Cultural Studies and Critical Pedagogies in Postmodern Spaces. London: Routledge. 
Harrison, B. (2004). Photographic visions and narrative inquiry. In M. Bamberg \& M. Andrews (eds.), (2004). Considering Counter-narratives: Narrating, Resisting, Making sense, 113-136, Amsterdam: John Benjamins.

Hočevar, U. (2010). Estetika reportažne fotografije. [The Aesthetic of photojournalism]. Ljubljana: Maska.

Jameson, F. (2001). Postmodernism, or, the Cultural Logic of late Capitalism. Durham, NC: Duke University Press.

Jontes, D. (2017). Between detachment and engagement: Paradoxes in reporting about the "refugee crisis" in the daily press. Two Homelands, 45, 185-200. Retrieved from: http://twohomelands.zrc-sazu.si/uploads/articles/1488026884_Be-

gunska\%20kriza\%20v\%20dnevnem\%20tisku_Jontes.pdf. Accessed 12 January 2020.

Kozol, W. (1994). Life's America. Philadelphia, PA: Temple University Press.

Kreft, L. (2010). Resnica v fotografiji [Truth in Photography]. In U. Hočevar (Ed.), Estetika reportažne fotografije (251-275). Ljubljana: Maska.

Leventhal, R.S. (1995). Art Spiegelman's MAUS: Working through the trauma of the Holocaust, Retrieved from: http://www2.iath.virginia.edu/holocaust/spiegelman.html. Accessed 2 December 2017.

Limone, N. (2012). Haaretz, 2012, August 16. Retrieved from: http://www.haaretz.com/weekend/magazine/germany-s-most-important-livingphilosopher-issues-an-urgent-call-to-restore-democracy.premium-1.458767. Accessed 16 December 2014.

Lunaček Brumen, S. \& Meh, E. (2016). The rise and fall of the corridor. Časopis za kritiko znanosti, 41(264), 21-45.

Luthar, B. (2017). Refugees and "Odmevi": The epistemology of conventions. Two Homelands, 45, 153-168. Retrieved from: http://twohomelands.zrc-sazu.si/uploads/articles/1488026584_Begunci\%20v\%200dmevih_Luthar.pdf. Accessed 12 January 2020.

McRobbie, A. (2006). Vulnerability, violence and (cosmopolitan) ethics: Butler's precarious life. British Journal of Sociology, 57(1), 69-86.

Mihelj, S. (2004). Negotiating european identity at the periphery: Media coverage of bosnian refugees and "illegal migration". In I. Bondebjerg \& P. Golding (eds.), European Culture and the Media (165-189). Bristol: Intellect.

Museum of Contemporary Art Metelkova, Ljubljana (MSUM) (2019). Southern constellations: The poetics of the non-aligned, 7 March - 10 September, Retrieved from: http://www.mg-lj.si/en/exhibitions/2439/southern-constellations-the-poetics-of-thenon-aligned. 
Pajnik, M. (2017). Media-political parallelism: Legitimization of migration policy in editorials in the daily newspaper Delo. Two Homelands, 45, 169-184. Retrieved from: http://twohomelands.zrc-sazu.si/uploads/articles/1488026761_Begunci\%20Delo_Pajnik.pdf. Accessed 12 January 2020.

Pajnik, M., Lesjak-Tušek, P. \& Gregorčič, M. (2001). Immigrants, who are you? Ljubljana: Peace Institute.

Pušnik, M. (2017). The dynamics of journalistic discourse on populism and extremism: Moralistic stories about refugees. Two Homelands, 45, 137-152. Retrieved from: http://twohomelands.zrc-sazu.si/uploads/articles/1488026427_Moralne\%20zgodbe_Pusnik.pdf. Accessed 12 January 2020.

Rosler, M. (1999). In, around, and afterthoughts (on social documentary). In R. Bolton (ed.), The Contest of Meaning: Critical Histories of Photography (287-301). Cambridge, MA: MIT Press.

Štiks, I. (2019). The 21st-century left and the spectres of Yugoslav socialism: Anti-fascism, non-alignment, self-management and multinational federalism. Conference paper presented to Non-Aligned Contemporaneity conference, MSUM, 27-28 May.

Velikonja, M. (2014). New Yugoslavism in contemporary popular music in Slovenia. In M. Velikonja \& D. Abazović (eds.), Post-Yugoslavia: New Cultural and Political Perspectives (57-95). London: Palgrave Macmillan.

Vezovnik, A. (2017). Otherness and victimhood in the tabloid press: The case of the "refugee crisis" in "Slovenske novice", Two Homelands, 45, 121-135. Retrieved from: http://twohomelands.zrc-

sazu.si/uploads/articles/1488026209_begunci\%20v\%20SNovicah_Vezovnik.pdf. Accessed 12 January 2020.

Vidmar Horvat, K. (2009). Zemljevidi vmesnosti [The maps of in-betweenness]. Ljubljana: Sophia.

Vidmar Horvat, K. (2012) Kozmopolitski patriotizem [Cosmopolitan patriotism]. Ljubljana: Faculty of Arts Publishing.

Vidmar Horvat, K. (2017). The Balkan Road and the guarding of Europe: The refugee crisis on the borders of Slovenia. Two Homelands, 45, 105-119. Retrieved from: http://twohomelands.zrc-sazu.si/uploads/articles/1488025214_Crisis\%20on\%20Slo\%20border_Vidmar\%20Horvat.pdf.

Violi, P. (2012). Trauma site museums and politics of memory: Tuol Sleng, Villa Grimaldi and the Bologna Ustica Museum. Theory, Culture and Society, 29(1), 36-75. doi: 10.1177/0263276411423035.

Wright, T. (2000). Refugees on screen. Oxford: Refugee Studies Centre, University of Oxford, Retrieved from: https://www.rsc.ox.ac.uk/publications/refugees-on-screen. 